Journal of Primary Education
$9(5)(2020): 546-553$
UNNES
https://journal.unnes.ac.id/sju/index.php/jpe

\title{
The Effectiveness of Storytelling and Roleplaying Media in Enhancing Early Childhood Empathy
}

\author{
Ratna Suryani $^{1 凶}$, Sugiyo Pranoto ${ }^{2}$, Budi Astuti ${ }^{2}$ \\ DOI: https://doi.org/ 10.15294/jpe.v9i5.43532 \\ 1. TK Ceria Anakku Semarang, Indonesia \\ 2. Pascasarjana, Universitas Negeri Semarang, Indonesia
}

\begin{tabular}{l} 
Article Info \\
\hline History Articles \\
Received: \\
22 September 2020 \\
Accepted: \\
23 October 2020 \\
Published: \\
31 December 2020 \\
\hline Keywords: \\
Empati, Mendongeng, \\
Bermain Peran,
\end{tabular}

\begin{abstract}
Kindergarten children's still have difficulty to work in a team. Some of them still focus on their own activities without regard to their friends. This shows that there are deficiencies in the learning process so that children empathy does not yet develop. The purpose of this study was to examine the effectiveness of storytelling and roleplaying media in increasing empathy skills of kindergarten students. The research method was a quasi-experimental design. The subject was kindergarten students who were within the age range of 5-6 in Genuk district in which samples were 31 students as the experimental class and 21 students as the control class. The data analysis technique used descriptive analysis, paired t-test, and independent t-test. The results showed that the storytelling and roleplaying media could significantly increase empathy of early childhood (AUD), the average score of AUD social empathy of the experimental class was higher than that of the control class and $32.46 \%$ of AUD social empathy in the experimental class was in the Developing as Expected (BSH). Therefore, it could be concluded that the application of storytelling and roleplaying method was effective in increasing social empathy skills compared to the application of storytelling media only.
\end{abstract}

\footnotetext{
$\triangle$ Correspondence address:

Perum. Sembungharjo Permai Blok D-24 Genuk

E-mail: ratnasuryanica@gmail.com
} 


\section{INTRODUCTION}

Education is indispensable asset for a nation's progress. Therefore, every citizen must follow the education level (Nisa ', 2017). Considering how important education is, the government also manages the most fundamental educational institution, namely Early Childhood Education (AUD). AUD Education which particularly refers to the 2013 curriculum, is based on fun learning with a learning model that is in accordance with the child's nature and world, which is playing. AUD learning is arranged in a planned and holistic manner, where children are given opportunities to explore their potential based on their abilities and levels of development during learning process. (Suarta, 2018).

AUD Education is an initial education to form stages of growth and development where children are stimulated by educational stimulations so that all aspects of their development develop optimally. One of aspects in the field of developing basic skills in AUD Education is the social emotional (Ariyanti, 2016). According to Wina et al. (2019), social emotional development is one of the important developments for children because they live based on their parents and families' environment in the community. Thus, the social emotional aspect plays an important role in determining children's success in the future.

The ability to behave socially needs to be owned by children since they were young as a foundation for their development ability to interact with their wider environment. According to Adrianinditha (2015), children who can socialize well based on their developmental stage and age tend to be sociable children. The inability of children to behave socially as expected by their environment can obstruct children development to control their emotions (Tatminingsih, 2019). This situation can cause children become excluded from the environment and have low self-confidence. Moreover, they will withdraw from the environment. AUD especially in the age of $5-6$ years, basically have a desire to be accepted by their group.

Many children, especially AUD, have difficulty in social interaction such as being afraid to speak or express their opinions, not paying attention when friends are talking, taking things without permission and being in power. These things are caused by lack children's social empathy. Poor social skills indicate anti-social behavior, not having a spirit of cooperation and empathy, liking to fight, and being alone.

Empathy is an attitude of how individual can acknowledge and understand others' feelings without experiencing themselves (Silfiasari, 2017). Children who have empathy are typically sensitive, understanding, and caring to others' feelings and able to identify them verbally. Zainudin \& Ediati (2016) state that empathy fundamentally exists in children, but if it is not improved, this ability will be lost. Therefore, empathy is incredibly good if instilled early. With enhanced empathy, hopefully children will be able to feel what other people feel and learn that not every wish can be fulfilled.

Kindergarten students in Genuk District, Semarang City, still have lack of empathy. Based on the observation, children still have difficulty to work in a team. Some of them still focus on their own activities without regard to their friends. This shows that there are deficiencies in the learning process so that children empathy does not yet develop. Responding to this problem, an effective learning strategy is needed to enhance children empathy skills. One strategy which can be applied is role playing and storytelling.

Storytelling and roleplaying media can be applied in the AUD learning, as stated by Nasution (2016), in general, in the development of children in the age of 5 to 6 , they have already associated with all their friends, shown tolerance towards others, and been able to play cooperatively (cooperative play). Playing can also prosper children's mental and emotional wellbeing. AUD period can be called as a playing period for children in which their daily is filled with playing activities with inner freedom so that they become more active, creative, and 
imaginative (Pravitasari, 2018). Hence, storytelling and roleplaying media can be an alternative method to increase AUD empathy.

The purpose of this study is to determine the effectiveness of storytelling and roleplaying media in developing and improving the empathy skills of AUD in Kindergarten, Genuk District, Semarang City.

\section{METHOD}

The research was used experimental research method, with a Quasi Experimental Design in the form of a Nonequivalent Control Group where two groups of subjects were given different treatments for a certain period of time. The subjects of this study were kindergarten students in the age of 5-6 years in the Genuk District which consisted of 2 groups of research subjects, namely the control class and the experimental class. The experimental class was a class which were given storytelling and roleplaying method, it was Ceria Anakku Kindergarten with 31 students. Then, the control class was a class that were given storytelling method, it was Insan Cendekia Kindergarten students with 21 students. Data collection techniques in this study were observation and interview.

The data analysis technique was the analysis of the effectiveness of learning method which consisted of descriptive analysis, paired ttest, and independent t-test. Descriptive analysis was used to analyze the description of student conditions or student activities in participating in the learning process. Paired t-test was used to analyze differences in conditions before and after being given treatment. Independent t-test was used to analyze the differences in the empathy scores of the experimental class and the control class. Data were analyzed by using Microsoft Excel and SPSS 20.

\section{RESULT AND DISCUSSION}

Child development refers to the increasing ability in more complex structure and function of child's body through stimulation in the learning process. One of important aspects of child development is emotional intelligence where IQ only contributes $20 \%$ to a person success, while the remaining $80 \%$ is influenced by emotional and spiritual intelligence (Nugraha et al., 2017).

The learning process that is performed in this model is a learning which increases the sense of social empathy through listening and playing activities so that children's stimulation of emotional intelligence occurs according to the need and level of development of AUD. The application of storytelling and roleplaying is a learning media that combines children ability to engage fairy tales which is read by the teacher and then imagine and play roles according to the story. According to Suarta (2018), the implementation of AUD is the world of play and children's development level of concrete sensorimotor and preoperational thinking. Therefore, this is not time for children to only be ordered to sit and hear the teacher's explanation which can lead their development to be less optimal. In this study, the told story was taken from the storybook of Peternakan Kakek Tulus which was arranged by The Commission on Corruption (KPK) and those stories were Terjebak di Kandang (a story about cooperation), Gara-Gara Rumput (a story about justice), Topeng Monyet (a story about concern), Akrobat Wortel (a story about honesty), and Kembali Terbang (a story about persistence). Hopefully, by giving these stories, AUD would be able to increase their empathy skill in every aspect of measurement.

The effectiveness of the application storytelling and roleplaying can be seen from the categories of AUD empathy development, AUD empathy enhancement, and higher social empathy skills compared to the control class. In this study, Kindergarten students from the control and experimental groups were observed their social empathy abilities before and after being given learning media. The results of observations before and after treatment are shown in Figure 1. 


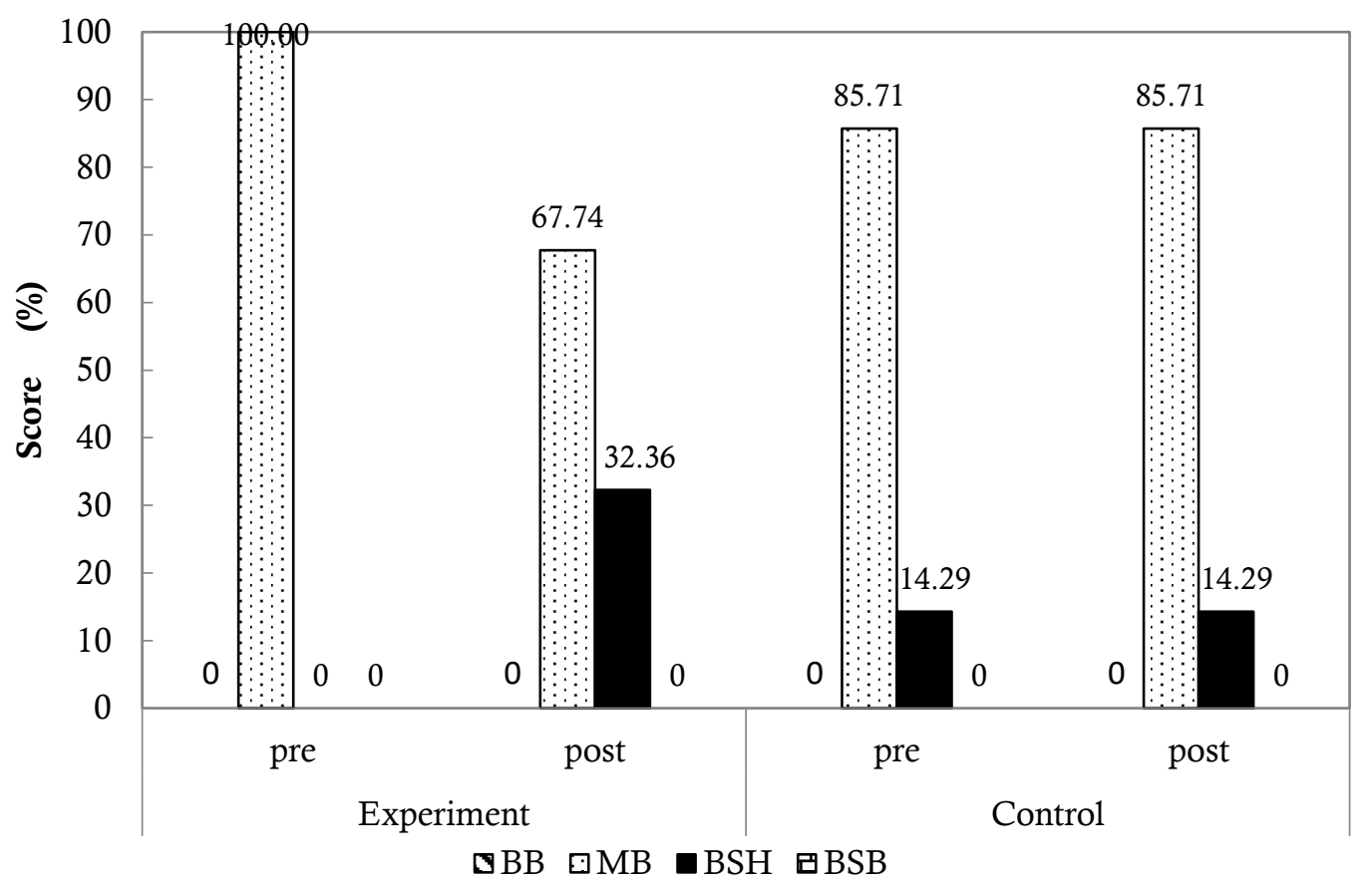

Figure 1. The Observation Result of Social Empathy Ability Score

Figure 1 described the observation result of the AUD' social empathy ability score which was categorized into 4, they were Not Developing (BB), Starting to Develop (MB), Developing according to Expectations (BSH), and Developing Very Well (BSB). The teacher follows standard-based assessment of AUD development, where if the child is in the BSH and BSB category, so the report must include strengths and recommendations, while if the child is in the BB category, the report is about a recommendation containing suggestions that parents can do toward their child during parenting. (Zahro, 2015).

Based on Figure 1, before being given storytelling and roleplaying method, all AUD in the experimental class was $100 \%$ of having social empathy skills, which was in the MB category, then after learning, it became $67.74 \%$ AUD which was in the MB category and $32.26 \%$ AUD had already been in the BSH category.

Furthermore, in the control class, there was no change in children social empathy skills before and after the application of storytelling learning media, this was proven by the same frequency distribution which was $85.71 \%$ of AUD in the MB category and $14.29 \%$ of AUD in the BSH category.

To determine the enhancement of the AUD social empathy ability score, a paired t-test was carried out. The test results for the experimental class and control class are shown in Table 1.

Table 1. The Result of Paired T-Test

\begin{tabular}{lccc}
\hline & tcount & Sig. & Explanation \\
\hline Experimental Class & 4.64 & 0.00 & Significant \\
Control Class & 0.54 & 0.60 & Not Significant \\
If the sig. value $<0.05$ then there is a significant increase in the empathy score \\
\hline
\end{tabular}


Based on data presented in Table 1, we know that there was a significant increase of the AUD's empathy score of the experimental class. This was shown by the sig. value of the experimental class which was $0.00<\alpha(0.05)$. Meanwhile, in the control class there was no increase of AUD's empathy score because the sig. in the control class was $0.6>\alpha(0.05)$. This is in line with the results of the previous descriptive analysis which stated that there was no change in the children's social empathy abilities in the control class. The increase of the average score of the experimental class AUD empathy ability was $9.46 \%$ which was higher than the control class by $1.66 \%$.
The test was continued by comparing the average of AUD's empathy ability score after the learning between the experimental and the control class by using the independent t-test. The test results by using SPSS 20 showed the sig. value ( 2 -tailed) was $0.018<\alpha(0.05)$, so it could be concluded that there was a significant difference in the average of AUD's social empathy ability score between the experimental and the control class. Since there was a significant difference, to find out the average score of the higher class empathy ability, we can see the average score of the AUD social empathy ability which is presented in Figure 2.

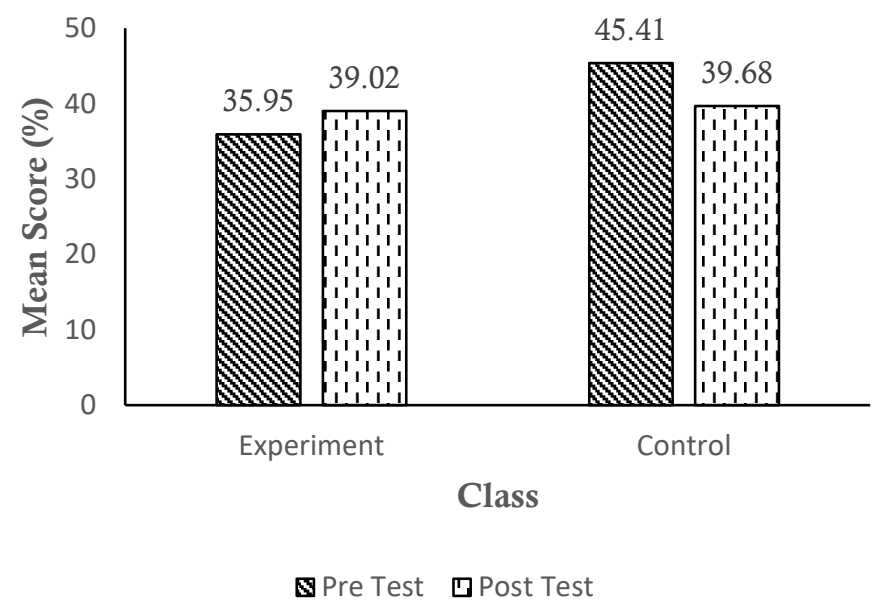

Figure 2. Mean of AUD Social Empathy Skills Score

In Figure 2, the post average score of AUD social empathy skills in the experimental class was $45.41 \%$ higher than the control class, which was $39.68 \%$. Thus, AUD who received storytelling and roleplaying method had a higher social empathy ability compared to AUD who received storytelling media only.

AUD empathy skill was measured by using 6 aspects of measurement, namely caring, helpful, respective, and tolerant, adaptive, responsible, acknowledging the emotion of oneself and others, and acknowledging needs, desires, and self-interests. The comparison score of AUD empathy skill of control and experimental class are presented in the and comparison chart in Table 2. 
Table 2. The Comparison Score of AUD Empathy Skill in Every Aspect

\begin{tabular}{lllll}
\hline \multirow{2}{*}{ Social Empathy Skills Aspect } & \multicolumn{3}{c}{ Control } & \multicolumn{3}{c}{ Experiment } \\
\cline { 2 - 5 } & pre & Post & pre & post \\
\hline Caring and Helpful & 39.42 & 36.64 & 37.63 & 42.20 \\
Respective and Tolerant & 37.70 & 37.90 & 35.35 & 43.28 \\
Adaptive & 34.23 & 40.48 & 31.85 & 42.54 \\
Responsible & 36.51 & 38.29 & 37.10 & 47.85 \\
Acknowledging the emotions of oneself and other & 39.29 & 46.43 & 35.69 & 47.78 \\
Acknowledging needs, desires, and self interest & 40.18 & 43.75 & 35.69 & 52.62 \\
\hline
\end{tabular}

The comparison score result in each aspect of measurement in Table 2 indicated that there was increased score of AUD empathy skill on each aspects of measurement. In the experimental class, the score was increasing between before and after learning process, in contrast with the control class which did not particularly improve and even it decreased on the aspect of caring and helpful. The highest score of AUD empathy skill in the experimental class was on the aspect of acknowledging needs, desires, and self-interests with a great score of $52,62 \%$. This proved that by applying storytelling and roleplaying media, AUD could express what they feel (hunger, thirst, stomach pain, cold, feeling of having a leak), choose the offered activities, know their own needs, and show their enthusiasm positively in a competitive game.

According to Tuanakotta \& Indianti (2018), children in the age of 5-6 years start to be able to understand other people's perspectives so that they can show their empathy for others. Furthermore, through fairy tales, children's perspective will be guided to the way where they can create empathy for all forms of life in the universe. Other studies revealed that there was a significant effect of the application of social stories media in increasing children empathy abilities (Ayuningtyas et al, 2016). The results of the study in the control class showed that there was no significant effect of the application of storytelling media only in increasing children social empathy skills. The reason for this was that listening to fairy tales can trigger children stimulus only to feel empathy which was different from play activities that could allow children to develop their empathy abilities.

When children are doing roleplay, they do not only act out the character's identity but also the thoughts and feelings. Consequently, this can help children to construct a better understanding towards others, become more tolerant, and enable to tolerate differences that they found. Purposes of using role play based on Sudjana in Harianja \& Nurihsan (2016) includes: (a) as children's motivation, (b) to attract children's interest and attention, (c) to provide opportunities for students to explore situations where they experience emotions, differences opinions and problems in the social life environment, (d) to encourage students to ask questions, to develop children's communication skills, and (f) to train children to take an active role in real life.

Handari (2018) also states that role-play technique is effective for improving social skills. Other research finding by Nurhasanah et al (2019) and Solikhah et al. (2019), report that role play media can increase children's empathy abilities in which this media has a positive effect where it can make children who are initially shy and have low motivation become very enthusiastic.

By combining these two media, AUD will undergo two stages, namely stimulus or triggering to feel empathy through fairy tales and the stage of developing their social empathy skills through role playing, so that it will be more effective in increasing AUD social empathy skills. The effectiveness of providing roleplaying and storytelling treatment on the 
development of kindergarten children's attitudes in Genuk sub-district is also supported by several things including the attention and activities of students, availability of media, the readiness of teachers / educators in providing learning to children.

\section{CONCLUSION}

Based on the data analysis, it can be drawn the conclusion that the application of storytelling and role playing media can enhance AUD social empathy skills. This is proven by an increase in the score of the experimental class by $9.56 \%$. In addition, it also shows that children in the control class has no scores differences on empathy abilities before and after the treatment was being given. Thus, it can be said that storytelling media followed by roleplaying is quite effective in increasing AUD social empathy skills.

\section{REFERENCES}

Ariyanti, T. (2016). Pentingnya Pendidikan Anak Usia Dini bagi Tumbuh Kembang Anak. Jurnal Dinamika Pendidikan Dasar. 8(1): 50-58.

Adrianindita, S. (2015). Upaya Meningkatkan Keterampilan Sosial-Emosional Anak Usia 2-3 Tahun Melalui Media Bercerita Di KB Siti Sulaechah 04 Semarang. Early Childhood Education Papers (BELIA). 4(2): 32-37.

Handari, S. (2018). Efektivitas Teknik Bermain Peran Untuk Meningkatkan Keterampilan Sosial Anak Kota Samarinda. HISBAH: Jurnal Bimbingan Konseling dan Dakwah Islam. 15(2): 45-65.

Harianja, S. I. \& Nurihsan A. J. (2016). Efektivitas Media Bermain Peran Dalam Meningkatkan Kemampuan Anak Usia Dini. Jurnal Kependidikan. 2(1): 59-71.

Nurhasanah, N., Neviyarni, S., \& Effendi, Z. M. (2019). The Effectiveness of Group Counseling With Role-Playing Techniques to Increase Stident Empathy.
International Journal of Applied Counseling and Social. 1(1): 54-61.

Nasution, D. (2016). Mengembangkan Sikap Sosial Anak Usia 5-6 Tahun dengan Media Pembelajaran Kooperatif. Jurnal Usia Dini. 2(1): 35-46.

Nisa', T. F. \& Karim, M. B. (2017). Profil Kemampuan Matematika Anak Usia Dini Melalui Learning To Think Different. PG-PAUD Trunojoyo. 4(2): 82170.

Pravitasari, I. R., Setyarini, D. I., \& Triningsih, R. W. (2018). Pengaruh Associative Play terhadap Tingkat Stress pada Anak Usia 3-5 Tahun. Jurnal Kesehatan Ibu Dan Anak. 4(1): 1-6.

Silfiasari, \& Prasetyaningrum, P. (2017). Empati dan Pemaafan dalam Hubungan Pertemanan Siswa Regular kepada Siswa Berkebutuhan Khusus (ABK) di Sekolah Inklusif. Jurnal Ilmiah Psikologi Terapan. 5(1): 126-143.

Solikhah, R. G., Fasikah, S. S., \& Amalia, S. (2019). Role Playing and Emotional Competence in School-Age Children (A Cusality Approach). Jurnal Psikologi Pendidikan \& Konseling. 5(2): 84-88.

Suarta, I N. \& Rahayu, D. I. (2018). Model Pembelajaran Holistik Integratif di PAUD untuk Mengembangkan Potensi Dasar Anak Usia Dini. Jurnal Ilmiah Profesi Pendidikan, 3(1): 37-45.

Tatminingsih, S. (2019). Kemampuan Sosial Emosional Anak Usia Dini di Nusa Tenggara Barat. Jurnal Obsesi: Jurnal Pendidikan Anak Usia Dini. 3(2): 484-493.

Tuanakotta, M. \& Indianti, W. (2018). Efektivitas Mendongeng Untuk Meningkatkan Pemahaman Respek Kepada Lingkungan Pada Anak Usia 5-6 Tahun. Jurnal Intervensi Psikologi. 10(2): 82-102.

Wina, R. P., Iriyanto, T., \& Aisyah, E. N. (2019). Pengembangan Permainan Harta Karun Si Bola-Bola dalam Pembelajaran Sosial EMosional Anak Usia 5-6 Tahun di Taman Kanak-Kanak. Jurnal Pendidikan Anak. 8(2): 126-131. 
Zahro, F. (2015). Penilaian Dalam Pembelajaran Anak Usia Dini. Tunas Siliwangi. 1(1): 92-111.

Zainudin, A. \& Ediati, A. (2016). Perbandingan Kemampuan Empati Anak Sebelum Dan
Sesudah Mendapatkan Pendidikan

Lingkungan. Jurnal Empati. 5(2): 367-372. 